\title{
Common Assessment Framework - Improving Organizational Performance of Municipalities in Bosnia and Herzegovina
}

\author{
Daut Bajramovic $^{1 *}$ ～Manfred Gram ${ }^{1}$ \\ ${ }^{1}$ American University in Bosnia and Herzegovina, Faculty of Economics, Sarajevo, Bosnia and Herzegovina
}

\begin{abstract}
Common Assessment Framework (CAF), a European Total Quality Management (TQM) methodology, has been applied by municipalities across Bosnia and Herzegovina (BiH) for a number of years. Municipalities have used CAF as a self-assessment tool to identify and meet their own development needs and improve organizational performance. Along with International Organization for Standardization (ISO) and Business Friendly Certificate (BFC) standards, CAF has been promoted by domestic non-governmental and international organizations as a TQM tool for public sector. This article provides an insight into experience of municipalities in $\mathrm{BiH}$ with implementation of CAF by focusing on their thematic priorities, organizational efficiency, output, outcome and citizens' satisfaction.
\end{abstract}

Key words: $C A F, T Q M$, organizational performance, outputs, outcomes and citizen's Satisfaction

JEL Classification: L38

\section{INTRODUCTION}

CAF is inspired by the Excellence Model of the European Foundation for Quality Management and the model of German University of Administrative Sciences in Speyer. It is based on the premise that excellent results in organizational performance in the public sector are achieved through effective leadership, planning, human resource management, partnerships and processes (The Common Assessment Framework Manual, OSCE, 2009). The pilot model was introduced in 2000, which was succeeded by revised versions in 2002, 2006 and 2013 (https://www.eipa.eu/portfolio/european-caf-resource-centre/)

At the end of 2016, around 4,000 public sector organizations have applied the model in 52 countries in and outside of Europe. Also, CAF Resource Centre of the European Institute of Public Administration has issued 185 CAF Effective User Labels. The CAF 2013 model has been translated in more than 25 languages (CAF Newsletter, 2017/1).

The CAF aims to be a catalyst for a full improvement process within the organization and has five main purposes (The Common Assessment Framework, 2013):

1. to introduce public administrations into the culture of excellence and the principles of TQM;

2. to guide them progressively to a fully-fledged PDCA (PLAN, DO, CHECK, ACT) cycle;

3. to facilitate the self-assessment of a public organization in order to obtain a diagnosis and a definition of improvement actions;

\footnotetext{
*E-mail: dtbc1155@aubih.edu
} 
4. to act as a bridge across the various models used in quality management, both in public and private sectors;

5. to facilitate bench learning between public sector organizations.

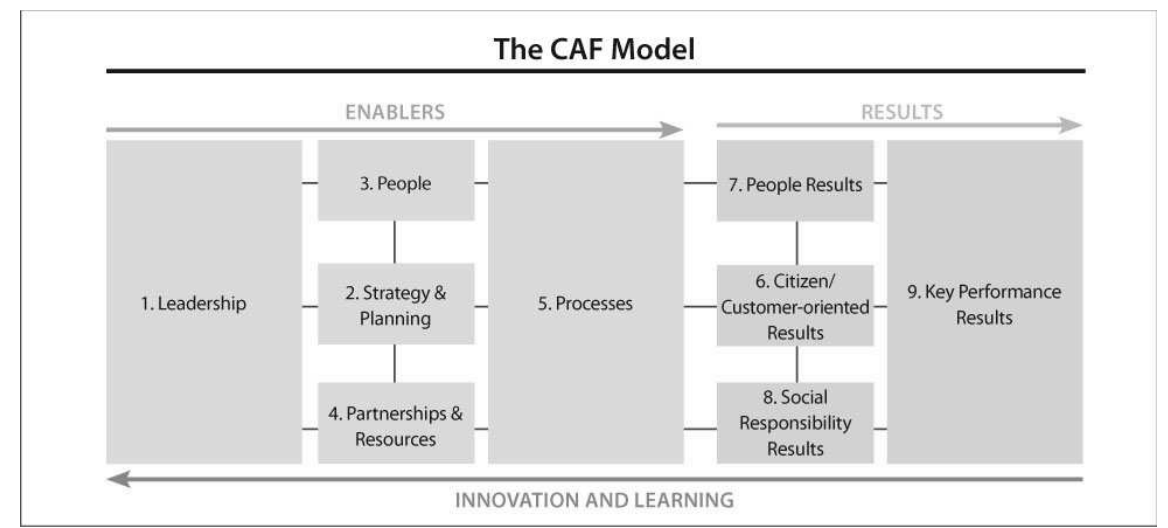

Figure 1. The CAF Model

Source: http://www.eipa.eu/en/topic/show/\&tid=191

Under the CAF Model (Figure 1.) assessment of public organization is measured against nine assessment criteria, five enablers and four results criteria.

In $\mathrm{BiH}$ initiation of application of CAF in public sector commenced around mid-2000s. Municipalities were then transitioning from the period of direct post-war recovery to a period of consolidation of administrative framework with more focus on their actual development needs. In this regard, municipalities saw $\mathrm{CAF}$, which was promoted by major international organizations in $\mathrm{BiH}$, as an opportunity for assessment of level of their development and identification of programmatic and administrative areas where improvements are needed. It was also seen as a tool that helps strengthening of good practices and development of new and innovative approaches. Since CAF is used by most EU countries municipalities also welcomed $\mathrm{CAF}$ as a tool for strengthening EU integration processes and taking ownership of the reform process.

\section{LITERATURE REVIEW}

Nowadays quality in public sector has been recognized as a critical strategic issue, which contributes to increase in performance efficiency and citizens' satisfaction, (Wisniewski, 1996; Montesinos \& Brusca, 2009; and Chiarini, 2016).

Total quality management (TQM) is a customer driven philosophy of quality, which focuses on building quality into the process and reflects the entire organization. It is built around seven concepts: 1) customer focus, 2) continuous improvement, 3) employee empowerment, 4) use of quality tools, 5) product design, 6) process management, and 7) managing supplier quality, Barnes (2008).

Application of concept of TQM, in public sector, started in late 1980s and early 1990s when US governmental agencies saw it as an agent for change and a mean to address citizens-related issues (Loomba \& Spencer, 1997). Milakovich (1991) notes that application of TQM techniques by federal, state, and local agencies responds to citizens' demands for better service quality, improves government's ability to effectively solve public problems, and provides a promising model for altering future public management practices.

Despite this, it has been challenging to obtain positive effects of application of TQM in reaching certain quality standards in service and particularly in public sector. Donelly (1999) 
problematizes quality in public sector by recognizing that increase in number of customer's results in higher demand for the offered services, while at the same time resources are kept constant. In this sense improvement in quality in public sector is limited to improvement of internal organization's operations instead of improving the final services in order to offer better, new, and more services.

Quality in public sector is characterized by three main features (Karyotakis, Moustakis, 2014):

1. Quality in sense of respect for rules and procedures

2. Quality in sense of achieving efficiency

3. Quality in sense of achieving citizens' satisfaction

Swiss (2014) underlines that adapted TQM, for public administration purpose, retains principles such as: employee empowerment, continuous improvement and quantities tracking of product quality and of client reactions.

According to Loomba and Spencer (1997) the greatest barrier to successful TQM implementation rests in the agency culture, organizational structure, and management policies. For good application of TQM methods in public sector they stress a need for employees at all levels to be trained, empowered and rewarded for teamwork. Furthermore, environment in the organization needs to foster open communication, teamwork and learning.

When compared to other TQM models, CAF is distinguished by two features: 1) it is a model developed specifically for the public sector, unlike several others which came and were adapted from the private sector and 2) it is a bottom-up approach with special focus on the crossdepartmental element in the composition of the self-assessment groups (Thijs, 2013).

Studying motives for use of CAF by Belgian public agencies Van Doren \& Van de Walle (2002) found that internal motivations (quality improvement) are of much greater importance than external motivations (use of CAF for budget maximization, promoting oneself or one's organization).

Since inception of CAF in year 2000, European Institute of Public Administration (www.eipa.eu) has been regularly collecting information from the Member States on use of CAF model, analyzing a need to improve the model, measure its impact and look for new opportunities for further spread. In 2011, after five years of implementing CAF 2006, EIPA surveyed 407 organizations from 27 countries. Survey showed that $60 \%$ of the organizations declared that the improvement actions, because of application of CAF have a large or very large impact on the functioning and results of the organization (Staes et al, 2011). In 2016, EIPA provided an overview of 20 good practices of application of CAF. In most case descriptions, clear data illustrated a link between better results of an organization and the undertaken improvement actions (Staes et al. 2016).

Interpreting numbers of CAF users from CAF Resource Centre in 2012 in comparison to size of individual EU countries Vrabkova (2013) finds that the highest implementation rate of CAF is in Poland, Denmark, Belgium and Portugal. The largest countries of EU Germany, Spain, France and including UK at that time reported very low implementation rate. Vrabkova (2013) further breaks down individual CAF users and their spheres of action and concludes that the highest percentage of organizations implement CAF in public administration (57\%), education sector (17\%), and defense, public policy and security (9\%).

\section{IMPLEMENTATION OF CAF IN BOSNIA AND HERZEGOVINA}

Implementation of Common Assessment Framework in municipalities was initially promoted by EDA - Agency for Development of Companies from Banja Luka and the Organization for Security and Cooperation in Europe, Mission to BiH.

EDA introduced CAF methodology, in period of 2004 - 2007, to seven partner municipalities: Doboj, Doboj Istok, Doboj Jug, Maglaj, Usora, Petrovo and Gracanica. Introduction of CAF 
methodology aimed to provide municipalities with the tool for monitoring of the processes at level of local self-government unit and tool for improving quality of administrative services (Draganic, 2006).

Draganic (2006) summarizes the major factors that contribute to sustainable implementation of the methodology, and those are the following:

a) Expression of interest and support from the municipal leadership;

b) Correct selection of members of CAF teams in terms of diversity and quality of their working experience;

c) Good level of relationship between the leadership and members of CAF teams;

d) Regular information sharing to all employees of the administration on implementation of CAF;

e) Well planned time for process of self-assessment;

f) Integration of projects from the Improvement plan into strategic planning at municipal level;

g) Correct adaptation of the methodology, especially self-assessment forms into specific context of local self-governance units.

OSCE Mission to BiH worked on introduction of CAF methodology through a local governance project named Local First Initiative (Inter-Municipal Learning and Support component), which was implemented in period of 2009 - 2012. The purpose of the Inter-Municipal Learning and Support component was to encourage municipalities to identify and meet their own development needs (Local First "Empowering Citizens - Building Communities", 2009). According to "Guide for better access to management of property at local level" from 2012 there were 36 municipalities in $\mathrm{BiH}$ that participated in Inter-Municipal Learning and Support Component and used CAF self-assessment methodology. Those are the following: Zenica, Kakanj, Maglaj, Travnik, Novo Sarajevo, Banja Luka, Bijeljina, Trebinje, Tomislavgrad, Vogošća, Tešanj, Rogatica, Višegrad, Bileća, Nevesinje, Ugljevik, Donji Vakuf, Bihać, Bileća, Cazin, Centar Sarajevo, Foča, Gacko, Goražde, Tuzla, Gračanica, Konjic, Jablanica, Kozarska Dubica, Modriča, Mrkonjić Grad, Lukavac, Novi Grad Sarajevo, Sanski Most, Ugljevik and Visoko.

In addition to municipal level higher levels of government in BiH also included CAF in their TQM aspirations. Since 2010 German Economic Development and Employment (GIZ) introduced $\mathrm{CAF}$ and other quality management techniques to the state and entity levels of government in $\mathrm{BiH}$ through Public Administration Reform Coordinator's Office of BiH (PARCO), State Civil Service Agency and Institute for Standardization of BiH. In February 2017 Council of Ministers of $\mathrm{BiH}$ recommended to the $\mathrm{BiH}$ state institutions to consider introduction of CAF and ISO standard. It also approved PARCO to be the contact point for CAF on behalf of BiH institutions.

Government of Republika Srpska (RS) in Strategy for Development of Local Self-governance from $2009 \quad$ (http://www.vladars.net/sr-SPCyrl/Vlada/Ministarstva/muls/OMin/Documents/Strategija\%20razvoja\%20lokalne\%20samou prave.pdf) defined a goal to stimulate and promote appropriate systems of quality management, CAF or ISO 9001:2000 in public services. Strategy for Development of Local Self-governance in RS for period of 2017-2021 (http://www.vladars.net/sr-SPCyrl/Vlada/Ministarstva/muls/Pages/default.aspx\#collapsible3) does not specifically refer to CAF; however it defines an objective "Ensure availability and quality of public services for all citizens".

In 2016 Government of Federation of $\mathrm{BiH}(\mathrm{FBiH})$ adopted Information on Commencement of Introduction of CAF methodology in Agency for Civil Service of FBiH. The Agency was tasked to prepare actions on introduction of CAF as a tool for assistance to organizations in public sector (http://www.fbihvlada.gov.ba/bosanski/sjednica_v2.php?sjed_id=560\&col=sjed_saopcenje). 


\section{SURVEYING MUNICIPALITIES IN BIH ON IMPLEMENTATION OF CAF}

In Bosnia and Herzegovina there has been little public information available on municipal experience in implementing CAF methodology. Several organizations and institutions do recommend and provide technical support on CAF; however, at the same time we lack an insight on actual impact of implementation of CAF to municipal organizational performances. In this regard, author of this article has designed a questionnaire to measure perception of civil servants, which were directly involved in implementation of CAF, on success rate of application of the methodology. It is to be noted that municipalities involved different departments and sectors as focal points for implementation of CAF i.e. Heads of Departments of General Affairs, Economy, Information Officers, ICT Administrators, Quality Assurance Officers and members of Mayors' Cabinets.

The questionnaire contained nine questions and was focused to measure the following variables: 1) years of implementation of CAF, 2) success of implementation of the methodology, 3) methodological focus of implementation of CAF, 4) citizens satisfaction, 5) organizational efficiency, 6) social accountability, 7) outputs, and 8) outcomes (see Appendix).

The questionnaire was sent out, via Survey Monkey service, to 36 municipalities that implemented CAF as part of the Inter-Municipal Learning and Support component of the Local First Initiative of the OSCE Mission to $\mathrm{BiH}$. As a result, 10 complete questionnaires have been filled out. Additional ten municipalities stated via direct contacts that they did not have enough institutional memory on results of implementation of CAF in period 2009-2011. The remaining 16 municipalities did not respond to the call for participation in the survey.

\section{RESULTS OF THE SURVEY}

Ten surveyed municipalities stated they had implemented CAF in different time frames from 1 to 5 years and more. Nowadays one municipality keeps applying CAF, while others shifted to implementation of ISO 9001 and Business Friendly Certificate (BFC). Business Friendly Certification South East Europe (www.bfc-see.org) is a unique program for improving the quality of services and information that municipalities in the SEE region offer to companies.

Most of municipalities that participated in the survey stated that their goal in implementing CAF was to improve citizens' satisfaction and management of processes and facts. In addition to this, municipalities also aimed at improving development of capacities and empowerment of employees and continuous innovation and improvements. No municipality answered that their goal in implementing CAF was to improve social responsibility.

Municipalities generally had positive experience with implementation of CAF methodology. Two of ten surveyed municipalities expressed negative opinion, Figure 2.

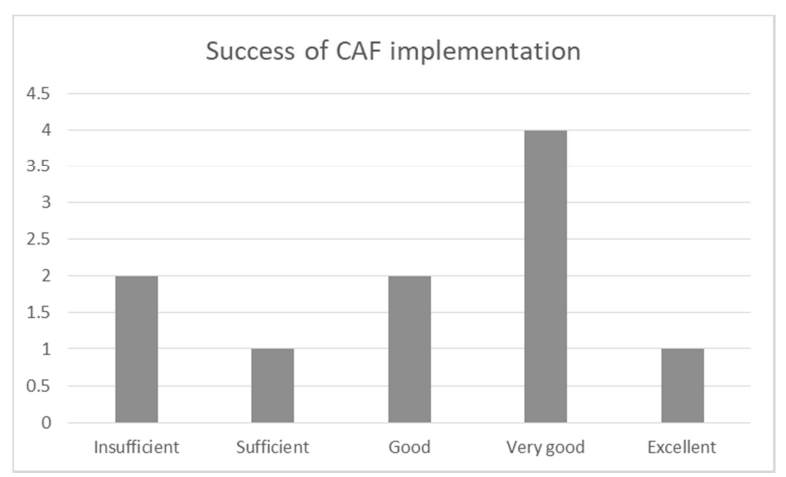

Figure 2. Municipal view on rate of success of CAF implementation 
Assessing success of implementation of CAF relating to increase of citizens' satisfaction, seven municipalities stated it had positive impact, while three claimed the impact was indifferent.

Internal efficiency of work got improved according to eight municipalities while two stated that impact was average. In terms of effects of implementation of CAF on socially responsible performance, responses of municipalities differed. Seven of them however reported positive impact. One on contrary noted no effect.

Surveyed municipalities indicated positive impact of CAF on municipal outputs i.e. management of budget, property, capital investments and projects, Figure 3.

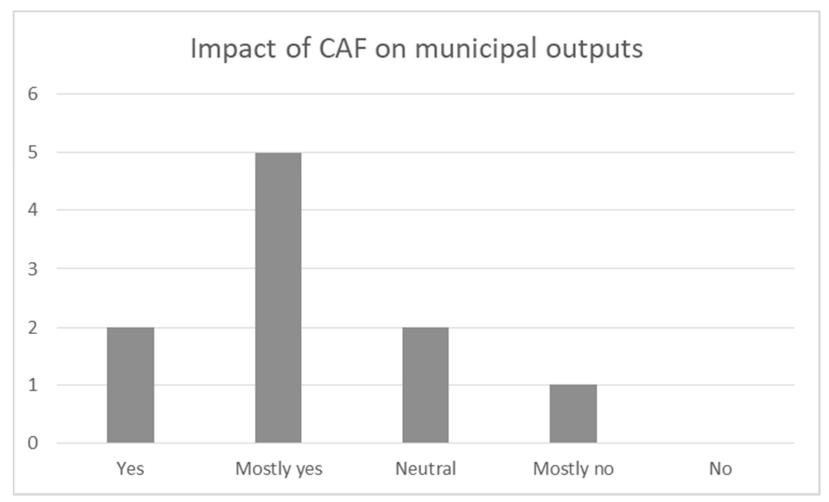

Figure 3. Impact of CAF on municipal outputs

Assessing outcome results or impact on indicators of development of communities, municipalities expressed more caution than with output, five reported positive impact, two indifferent, while three in the end saw no impact of CAF, Figure 4.

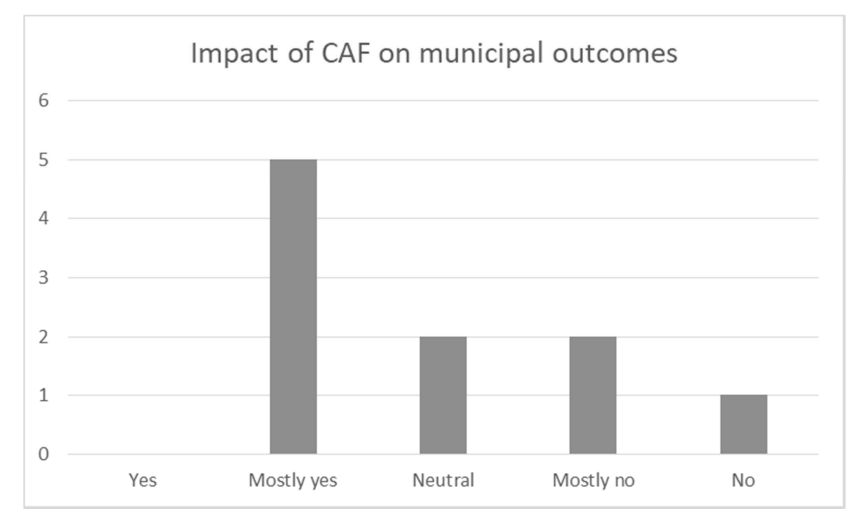

Figure 4. Impact of CAF on municipal outcomes, development of municipality

\section{CONCLUSIONS}

This research indicated that success of implementation of CAF at municipal level in $\mathrm{BiH}$ has been modest. Ten municipalities responded to the survey, ten did not have adequate institutional memory to respond to the survey, while sixteen of them did not participate in the survey for unknown reason. It is also indicative that one municipality out of ten surveyed continues to apply CAF. At the same time, municipalities that responded to the survey view CAF as a methodology worth applying and find support of the leadership being critical success factor. Responses of the municipalities also show that they achieved the best results in improving efficiency of work of their administrations and increasing citizens' satisfaction. As expected, 
municipal respondents found it most difficult to associate implementation of CAF to indicators of development of local community. Considering that functional and result oriented municipality is needed but at the same time also insufficient condition for ensuring development of the community, this latest conclusion does seem sensible.

Observing the trend of application of CAF in different levels of government in $\mathrm{BiH}$ it is noticeable that through PARCO and entities' civil service agencies higher levels get the deserved attention. Moreover, CAF and ISO are regularly jointly recommended as TQM standards.

Municipalities on the other hand, which had focus on CAF earlier, are now being "left" on their own due to lack of institutional support. Entities associations of cities and municipalities in $\mathrm{BiH}$ do not actively promote implementation of CAF at municipal level. It is also noted that municipalities now more favor introduction of ISO 9001 quality standard. Lack of institutional support for CAF and presence of different professional agencies that promote ISO in BiH can be seen as one of the reasons for this increased application of ISO by municipalities in BiH.

Nevertheless, CAF remains to be the TQM standard developed by the public sector for public sector, which is free of charge. Institutional support for CAF at higher levels of government in $\mathrm{BiH}$ is encouraging and welcomed. For the municipal level, entities associations of cities and municipalities should consider developing special program of institutional support for introduction and implementation of CAF. Relatively positive experience in implementing CAF and provision of institutional support will be a good reason for municipalities to introduce or revisit the TQM standard in way public institutions should do.

\section{ACKNOWLEDGMENTS}

Hereby I wish to thank all municipalities for their participation in the survey.

\section{REFERENCES}

Barnes, David. 2008. “Operations Management: An International Perspective.” South-Western Cengage Learning.

Chiarini, Andrea. 2016. "Strategies for improving performance in the Italian local government organizations. Can ISO 9001 really help?" International Journal of Quality \& Reliability Management, Vol. 33 Iss 3 pp.

Draganic, Aleksandar. 2006. "Kako da usavršimo lokalnu upravu po CAF metodologiji." EDA 2006. https://edabl.org/pub/edasr/

Drucker, Peter F. (1980). "The Deadly Sins in Public Administration". Public Administration Review, Vol. 40, No. 2 (Mar. - Apr., 1980), pp. 103-106

European Institute for Public Administration. 2017. "The Common Assessment Framework (CAF) Improving Public Organisations through Self-Assessment.". CAF Resource Centre. EIPA. European Public Administration Network. https://www.eipa.eu/portfolio/european-cafresource-centre/ (accessed January 2018)

Karyotakis, Konstantinos and Moustakis, Vassills. 2014. "Total Quality Management and Change Management in Public Organizations." Sinteza, Međunarodna naučna konferencija Univerziteta Singidurum.

Loomba, Arvinder and Spencer, Michael. 1997. "A Model for Institutionalizing TQM in a state government agency." International Journal of Quality and Reliability Management, Vol. 14 No. 8, 1997, pp 753-767

Milakovich, Michael E. 1991. "Total Quality Management in the Public Sector.” National Productivity Review 1991.

Montesinos and Isabel Brusca. 2009. "Towards Performance, Quality and Environmental Management in Local Government: the Case of Spain." Local Government Studies, 35:2, 197212 
OSCE Mission to BiH. 2017. "Local First "Empowering Citizens - Building Communities." http://www.osce.org/bih/110194?download=true (accessed September 2017)

Savez općina i gradova Federacije Bosne i Hercegovine. 2017. "Vodič za bolji pristup upravljanju imovinom na lokalnom nivou." Mreža općina/opština partnerstvo i resursi "PARES" (accessed august 2017).

Staes, Thijs and Dorina Claessens. 2016. "CAF Improvement, identification, prioritization and implementation." European Institute of Public Administration, CAF Resource Centre

Staes, Thijs, Soffels and Sven Geldof. 2011. "Five Years of CAF 2006: From Adolescence to Maturity - What Next?." European Institute of Public Administration, CAF Resource Centre

Swiss, James E. 1992. "Adapting Total Quality Management (TQM) to Government." Public Administration Review, Vol. 52, No. 4 (Jul. - Aug., 1992), pp. 356-362

Thijs, Nick. 2013. "How the CAF Model Strengthens Staff Participation." European Institute of Public Administration, CAF Resource Centre

Van Dooren, W. \& Van de Walle, S. 2004. "Why Do Belgian Public Agencies Use the Common Assessment Framework (CAF)?" In: Löffler, E. \& Vintar, M. (eds.). Improving the quality of East and Western European Public Services, Hampshire: Ashgate, pp. 157-71.

Vlada $\quad$ FBiH. 2017.2 "Saopćenje. "http://www.fbihvlada.gov.ba/bosanski/sjednica_v2.php?sjed_id=560\&col=sjed_saopcenje (accessed September 2017)

Vlada RS. 2017. "Draft Strategy on Development of local self-government of RS." http://www.vladars.net/sr-SP-Cyrl/Vlada/Ministarstva/muls/OMin/Documents/.

Vlada RS. 2017. "Strategy on Development of local self-government of RS for period of 20172021". http://www.vladars.net/sr-SPCyrl/Vlada/Ministarstva/muls/Pages/default.aspx\#collapsible2 (accessed September 2017)

Vrabkova I. 2013. "Quality Management in Public Sector: Perspectives of Common Assessment Framework Model in the European Union". ActA všfs, 2/2013, vol. 7

Wisniewski, Mik. 1996. "Measuring service quality in the public sector: The potential for SERVQUAL," Total Quality Management, 7:4, 357-366 


\section{APPENDIX}

\section{Improving organizational performances of units of local self-governance by Implementing} common assessment framework methodology - questionnaire

1. How many years have you implemented/been implementing CAF methodology?
a. 1
b. 2
c. 3
d. 4
e. 5 and more

2. How would you assess the rate of sucess of implemntation of CAF methodology in your local self-governance?
a. Unsatisfactory
b. Satisfactory
c. Good
d. Very good
e. Excelent

3. Does your local self-governance currently apply a methodology of Total Quality Management?
a. CAF
b. ISO
c. Other

4. What was / is your focus in applying CAF methodology? (please rank your answeres)
a. Results
b. Citizens' satisfaction
c. Management and constancy of fulfilling the purpose
d. Management of processes and facts
e. Development of capacities and inclusion of employees
f. Continuous inovation and improvements
g. Development and maintaing of partnerships
h. Social accountability

5. Has your measurements, during implementaiton of CAF, showed an increase of the degree of citizens's satisfaction with overall work of the local self-governance?
a. Yes
b. Mostly yes
c. Neither yes or no
d. Mostly no
e. No

6. Has your measurement, during implementation of CAF, showed improvements regarding internal indicators of efficiency of local sef-governance?
a. Yes
b. Mostly yes
c. Neither yes or no
d. Mostly no
e. No 
7. Has your measurement, during implementation of CAF, showed improvements regarding socially responsible actions of local self-governance (i.e. environment protection, support to minorities and persons with special needs, philantropic activities, social engagement etc)?
a. Yes
b. Mostly yes
c. Neither yes or no
d. Mostly no
e. No

8. Has your measurement, during implementation of CAF, showed improvements regarding outputs of perfomance of local self-government unit (budget management, management of property, management of capital investments, management of projects)?
a. Yes
b. Mostly yes
c. Neither yes or no
d. Mostly no
e. No

9. Has your measurement, during implementation of CAF, showed improvements against indicators of development of local community (number of employed, number of unemployed, number of registered businesses, improvements in infrastructure etc)?
a. Yes
b. Mostly yes
c. Neither yes or no
d. Mostly no
e. No

Article history: $\quad$ Received: January 6, 2018

Accepted: June 7, 2018 